\title{
MINIREVIEW
}

\section{Transolfactory neuroinvasion by viruses threatens the human brain}

\author{
I. MORI
}

Faculty of Health and Nutrition, Shubun University, Aichi 491-0938, Japan

Received February 9, 2015; revised April 20, 2015; accepted October 2, 2015

\begin{abstract}
Summary. - Viral neuroinvasion via the olfactory system has been investigated in a variety of virus-animal models by scientists in many fields including virologists, pathologists, and neurologists. In humans, herpes simplex virus type 1 (HSV-1), human herpesvirus 6 (HHV-6), Borna disease virus, rabies virus, and influenza A virus have been shown to take the olfactory route for neuroinvasion based on forensic and post-mortem specimens. This article briefly summarizes the anatomy, physiology, and immunology of the olfactory system and presents a battery of neurovirulent viruses that may threaten the human brain by invading through this peripheral pathway, especially focusing on two of the most intensively studied viruses - HSV-1 and influenza A virus. Viruses may insidiously invade the olfactory neural network not only to precipitate encephalitis/encephalopathy but also to promote the development of neurodegenerative and demyelinating disorders. Substantial information obtained by analyzing human specimens is required to argue for or against this hypothesis.
\end{abstract}

Keywords: virus; olfactory neuron; human brain; encephalitis; neurodegenerative disorders

\section{Contents:}

1. Introduction

2. The olfactory system

3. Innate immunity in the olfactory system

4. Transolfactory neuroinvasion by neurotropic viruses in humans

5. The vomeronasal system as a route of neuroinvasion by neurotropic viruses

6. Herpes simplex virus (HSV)

7. Herpes simplex encephalitis (HSE)

8. Role of HSV accessory genes in the olfactory neuroinvasion

9. HSV latency and persistency in the central nervous system

E-mail: mori@shubun-ac.jp; phone: +81-586-45-2101

Abbreviations: $\mathrm{CNS}=$ central nervous system; $\mathrm{CSF}=$ cerebrospinal fluid; HHV-6 = human herpesvirus 6; HPAI = highly pathogenic avian influenza; $\mathrm{HSE}=$ herpes simplex encephalitis; HSV-1 = herpes simplex virus type 1 ; IFN = interferon; ORNs = olfactory receptor neurons; RIG-1 = retinoic acid inducible gene 1; TLR3 = toll-like receptor 3
10. Influenza A virus

11. Highly pathogenic avian influenza

12. Influenza A virus in human olfactory nervous tissues

13. Concluding remarks

\section{Introduction}

To gain access to the central nervous system (CNS), neurotropic viruses exploit a variety of peripheral neural pathways as well as the hematogenous route (Kristensson, 2011). Neurons are highly polarized cells with structurally and functionally distinct processes known as dendrites and axons that can be separated by large distances. Axons have a uniform arrangement of microtubules with plus ends that are distal to the cell body (plus-end-out), whereas dendrites have equal numbers of plus- and minus-end-out microtubules. Kinesin and dynein serve as motor proteins for anterograde and retrograde transports, respectively, of macromolecules along microtubules. Infectious agents usurp this transport system to gain entry into the nervous 
system. HSV is rapidly transported along microtubules in the anterograde direction from the soma to the axon terminus and retrogradely in the opposite direction. Viral capsid/ tegument and glycoproteins synthesized in the soma may be separately transported in the anterograde direction down the axons. They likely accumulate in varicosities and growth cones, where capsids invaginate vesicles and acquire their envelope glycoproteins (Diefenbach et al., 2008).

\section{The olfactory system}

Olfactory mucosa lines the posterodorsal nasal cavity in terrestrial animals. The olfactory neuroepithelium consists of a limited number of cell types that are arranged in a roughly laminar pattern, with sustentacular cells in the most apical location, followed by olfactory receptor neurons (ORNs) and then basal cells (Mori et al., 2005a; Gizurarson, 2012). Sustentacular cells perform a number of glial-like neuroprotective functions, and they express high levels of cytochrome P450 isoforms and glutathione S-transferases (Rodriguez et al., 2008). Mature ORNs are bipolar sensory receptors with an apical dendrite ending in a knob covered by 12 or more cilia over its apical surface in the neuroepithelium. Basal cells are multipotent progenitors that give rise to ORNs throughout the life of the animal. Unmyelinated axons of ORNs leave the neuroepithelium, penetrate the cribriform plate, enter the olfactory bulb, and form synapses in the glomeruli with dendrites of second-order neurons, i.e., mitral/tufted cells. Mitral/tufted cells, in turn, project centrally to olfactory and limbic structures, including the anterior olfactory nucleus, olfactory tubercle, olfactory cortex, amygdala, and entorhinal cortex. On the other hand, the olfactory bulb has retrograde connections with the cholinergic diagonal band, serotonergic dorsal raphe, and noradrenergic locus coeruleus. Additionally, dopaminergic neurons in the ventral tegmental area project to the anterior olfactory nucleus. Once in the olfactory bulb, neurotropic viruses can target these brain structures in both anterograde and retrograde manners.

The olfactory system exhibits several unique properties that are not typical of other sensory systems. First, the receptor molecules of ORNs are directly exposed to the external environment so that they are able to respond to volatile chemical stimuli. Second, these neurons have the capacity for uptake and transsynaptic transport of exogenous substances to the CNS. Third, the olfactory system forms direct connections to the frontal cortex without thalamic relay, whereas other sensory pathways of the visual, auditory, and somatosensory modalities consistently pass through the thalamus. Finally, similar to other epithelial cells, but unlike other neurons, ORNs undergo apoptosis and regeneration as a part of their normal turnover process that continues throughout adult life and they have an average life span ranging from 30 to 120 days (Oboti et al., 2011). Furthermore, neuronal stem cells in the subventricular zone of the adult brain predominantly migrate into the olfactory bulb, likely protecting the olfactory bulb neuronal circuits from damage by infectious and toxic agents (Loseva et al., 2009). The physiological processes of uptake and transsynaptic transport of molecules from the nasal cavity to the olfactory bulb potentially pose great risks for the CNS, namely neurological damage induced by environmental factors including viruses.

In addition, axons of ORNs cross the cribriform plate through channels formed by olfactory ensheathing cells. These channels penetrate into the ventral portion of the olfactory bulb and may serve as a potential entry route for viruses into the brain. Viruses may also cause early meningoencephalitis by entering the cerebrospinal fluid (CSF) from infected olfactory ensheathing cells (Bodewes et al., 2011). This notion of alternative olfactory pathway for neuroinvasion by viruses is supported by an in vitro study that demonstrated human herpes virus 6 (HHV-6) replication in olfactory ensheathing cells (Harberts et al., 2011). Furthermore, the PR8 strain of influenza A virus (H1N1), a non-neurotropic virus, may also infect olfactory ensheathing cells as well as microglia/macrophages along the olfactory nerve fibers (Leyva-Grado et al., 2009). It should be noted that the olfactory mucosa is also innervated by fibers from the trigeminal nerve, autonomic fibers of the cervical ganglion, and the nervus terminalis (Vilensky, 2014). The olfactory nerve, however, connects the nasal cavity directly with the CNS and may therefore be a fast and easy shortcut for viruses to invade the CNS (van Riel et al., 2015).

\section{Innate immunity in the olfactory system}

Innate immunity plays a central role in CNS protection against a variety of neurotropic viruses (Carty et al., 2014). Within the olfactory bulb, interferon (IFN)- $\alpha / \beta$-dependent antiviral mechanisms efficiently inhibit viral spread and serve as a barrier against intranasally invading neurotropic viruses (Kalinke et al., 2011). Toll-like receptor 3 (TLR3) expression was significantly increased in the olfactory bulb of mice after intranasal pretreatment with polyinosinic-polycytidylic acid, a TLR3 agonist, and it conferred protection against a lethal intranasal challenge with HSV-1 (Boivin et al., 2008). TLR3 activation by dsRNA (synthetic or virus-derived) triggers downstream signals that lead to the activation of the IFN- $\beta$ promoter. Recently, it has been shown that local olfactory bulb infection with both DNA and RNA viruses activates long-distance signaling that upregulates IFN-stimulated gene expression in uninfected remote regions of the mouse brain (van den Pol et al., 2014). In the absence of the IFN- $\alpha / \beta$ receptor, the brain was more vulnerable to viral infection due to the impaired induction of IFN-stimulated genes. 
In addition, Iba1-immunopositive microglia/macrophages, the principal resident innate immune cells in the CNS, reside in the murine olfactory neuroepithelium where they undergo dynamic morphological reactions upon intranasal influenza A virus infection (Mori et al., 2002). OX42-immunopositive microglia/macrophages also appear in the rat olfactory neuroepithelium after bulbectomy and participate in phagocytic activities (Suzuki et al., 1995). In addition, Iba1-/annexin A3-immunopositive microglia/macrophages reside in the olfactory nerve fascicles of adult rats and cats (Smithson and Kawaja, 2010). These peripheral microglia/macrophages may play a key role in TLR3 responses and downstream antiviral IFN signaling (Suh et al., 2009). On the other hand, adaptive immune responses barely contribute to neuroprotection against viral attack in the olfactory neuroepithelium (Tan and Stevenson, 2014). Neuroepithelial HSV-1 infection failed to elicit significant virus-specific antibody responses in the nasalassociated lymphoid tissue. Thus, innate immunity, especially IFN- $\alpha / \beta$-dependent mechanisms, serves as the first-line defense against invading intranasal viruses.

Viruses seek to subvert host immune responses. For example, distinct amino-acid motif in the polymerase of influenza A virus, $\mathrm{PB} 1 / \mathrm{PA}$, interacts with retinoic acid inducible gene 1 (RIG-1) that subsequently inhibits RIG-1-mediated IFN signaling (Liedmann et al., 2014). Additionally, the expression of annexin $\mathrm{V}$ in influenza A virus particles inhibits IFN- $\gamma$ antiviral immune responses (Berri et al., 2014).

\section{Transolfactory neuroinvasion by neurotropic viruses in humans}

Accumulating evidence supports the notion that certain neurotropic viruses enter the human brain via an olfactory transmission mechanism, namely HSV-1, HSV-2, HHV-6, Borna disease virus, rabies virus, influenza A virus, measles virus, Hendra virus, Nipah virus, and poliovirus (Table 1). Among these viruses, HSV-1, HHV-6, Borna disease virus, rabies virus, and influenza A virus have been detected in the human olfactory tissue samples.

In experimental settings, the olfactory pathway can also provide a route of neuroinvasion by some human neurotropic arthropod-borne viruses (arboviruses) including La Cross virus, Japanese encephalitis virus, Murray Valley encephalitis virus, St. Louis encephalitis virus, West Nile virus, Chikungunya virus, and Venezuelan equine encephalitis virus (Table 1). Of note, La Crosse virus, Murray Valley encephalitis virus, St. Louis encephalitis virus, and Venezuelan equine encephalitis virus infect the olfactory neuroepithelium after intraperitoneal or footpad subcutaneous challenge, probably via the hematogenous route, which is likely due to the unmyelinated nature of ORNs and the absence of a neuroprotective architecture equivalent to the blood-brain barrier of the CNS in the neuroepithelium (Charles et al., 1995; McMinn et al., 1996). This phenomenon is of particular interest because infectious virus particles could be released from infected ORNs into the nasal cavity, creating a potential source of droplet infection to other individuals.

The transmission of arboviruses without involvement of arthropod vectors is often termed direct transmission. This mode of viral transmission has been demonstrated in various experimental virus-animal models and may be common among wild and domestic animals (Kuno, 2001). The practical importance of such direct transmission of arboviruses has been recognized with respect to livestock-mediated as well as laboratory-acquired human infections. Arbovirus, especially present in the form of aerosols, could incidentally access the human brain through the olfactory route (Johnson and Mims, 1968). Thus, it is reasonable to assign a biosafety level to each arbovirus for protection of laboratory workers against accidental infections (Kuno, 2001).

\section{The vomeronasal system as a route of neuroinvasion by neurotropic viruses}

The vomeronasal organ, a second peripheral chemosensory module in the nasal cavity, has attracted increased scientific attention as a primary sensor for detecting pheromones in vertebrates (Ibarra-Soria et al., 2014). This bilateral, cigarshaped organ is encapsulated in a bony and/or cartilaginous capsule known as the vomer. It is located at the base of the nasal septum, anterior and ventral to the main olfactory neuroepithelium. The vomeronasal organ contains bipolar chemosensory neurons and its axonal nerve fascicles cross the cribriform plate to terminate in the accessory olfactory bulb. In mice, HSV-1 and HSV-2 enter the brain by infecting vomeronasal chemosensory neurons, in addition to the olfactory counterparts, following experimental intranasal inoculation (Mori et al., 2005b,c, 2006). HSV-1 infection is further transmitted from the accessory olfactory bulb (first relay) to the medial amygdala (secondary relay), and then to the bed nucleus of the stria terminalis and the ventromedial hypothalamus (third relay). Although pheromone-mediated controls of human behaviors have been recorded, the presence of the functional vomeronasal organ in humans, however, still remains controversial (Gizurarson, 2012; Verhaeghe et al., 2013). The neuroinvasion of neurotropic microbes via this route will mean a lot to non-human vertebrates, which could explain various abnormal behaviors of infected animals.

\section{Herpes simplex virus (HSV)}

Herpesvirus lineages have emerged by virtue of coevolution with their specific hosts, that is to say, cospeciation. The 
Table 1. Neurotropic viruses that may invade the human brain through the olfactory pathway

\begin{tabular}{|c|c|c|c|c|c|}
\hline Virus & Family & Subfamily & Genus & Notes & References \\
\hline HSV-1/HSV-2 & Herpesviridae & Alphaherpesvirinae & Simplexvirus & See details in text. & \\
\hline HHV-6 & Herpesviridae & Betaherpesvirinae & Roseolovirus & $\begin{array}{l}\text { Frequently detected by PCR in the olfactory bulb/ } \\
\text { tract specimens of human autopsy cases. }\end{array}$ & Harberts et al., 2011 \\
\hline \multirow[t]{4}{*}{ Borna disease virus } & Bornaviridae & & Bornavirus & $\begin{array}{l}\text { Infects ORNs and spreads intraaxonally to the } \\
\text { limbic structures in rats }{ }^{\mathrm{a}} \text {. }\end{array}$ & Carbone et al., 1987 \\
\hline & & & & $\begin{array}{l}\text { Infects ORNs and spreads to the brain in sponta- } \\
\text { neously and intranasally infected rats. }\end{array}$ & Morales et al., 1988 \\
\hline & & & & $\begin{array}{l}\text { Spreads into the brain via the olfactory route } \\
\text { during rat cohabitation experiments. }\end{array}$ & $\begin{array}{l}\text { Sauder and Staeheli, } \\
2003\end{array}$ \\
\hline & & & & $\begin{array}{l}\text { Detected by PCR in the olfactory bulb and related } \\
\text { regions in human autopsy brain tissues. }\end{array}$ & Haga et al., 1997 \\
\hline \multirow[t]{2}{*}{ Rabies virus } & Rabdoviridae & & Lyssavirus & $\begin{array}{l}\text { Infects ORNs and performs strict transsynaptic } \\
\text { transmission in mice }{ }^{\mathrm{a}} \text {. }\end{array}$ & Lafay et al., 1991 \\
\hline & & & & $\begin{array}{l}\text { Caused airborne rabies in a laboratory worker } \\
\text { with neuroinvasion via the olfactory route. }\end{array}$ & Conomy et al., 1977 \\
\hline Influenza A virus & & Orthomyxoviridae & $\begin{array}{l}\text { Influenza } \\
\text { virus } A\end{array}$ & See details in text. & \\
\hline Measles virus & Paramyxoviridae & Paramyxovirinae & Morbillivirus & $\begin{array}{l}\text { Spreads via the olfactory pathway to the olfactory } \\
\text { and limbic systems in hamsters }{ }^{\mathrm{a}} \text {. }\end{array}$ & $\begin{array}{l}\text { Zlotnik and Grant, } \\
1976\end{array}$ \\
\hline Hendra virus & Paramyxoviridae & Paramyxovirinae & Henipavirus & $\begin{array}{l}\text { Infects ORNs and spreads to the olfactory/limbic } \\
\text { systems in aged mice without viremia }{ }^{\mathrm{a}} \text {. }\end{array}$ & Dups et al., 2012 \\
\hline Nipah virus & Paramyxoviridae & Paramyxovirinae & Henipavirus & $\begin{array}{l}\text { Infects ORNs and spreads intraaxonally through- } \\
\text { out the CNS in hamsters }{ }^{\mathrm{a}} \text {. }\end{array}$ & Munster et al., 2012 \\
\hline La Crosse virus ${ }^{\mathrm{b}}$ & Bunyaviridae & & Bunyavirus & $\begin{array}{l}\text { Infects ORNs and spreads centripetally in mice } \\
\text { after intraperitoneal injection. }\end{array}$ & Bennet et al., 2008 \\
\hline \multirow[t]{3}{*}{ Poliovirus } & Picornaviridae & & Enterovirus & $\begin{array}{l}\text { Infects the olfactory bulb and spreads centrip- } \\
\text { etally initiating paralysis in monkeys }{ }^{\mathrm{a}} \text {. }\end{array}$ & $\begin{array}{l}\text { Sabin and Olitsky, } \\
1938\end{array}$ \\
\hline & & & & $\begin{array}{l}\text { Takes the olfactory route for neuroinvasion in } \\
\text { monkeys after droplet nuclei infection. }\end{array}$ & Faber et al., 1944 \\
\hline & & & & $\begin{array}{l}\text { Infects the olfactory bulb and spreads centrip- } \\
\text { etally in poliovirus receptor transgenic mice }{ }^{\mathrm{a}} \text {. }\end{array}$ & Crotty et al., 2002 \\
\hline $\begin{array}{l}\text { Japanese encephalitis } \\
\text { virus }^{\text {b }}\end{array}$ & Flaviviridae & & Flavivirus & $\begin{array}{l}\text { Infects the olfactory bulb and spreads to the } \\
\text { olfactory tract/cortex in piglets }{ }^{\text {a }} \text {. }\end{array}$ & Yamada et al., 2009 \\
\hline $\begin{array}{l}\text { Murray Valley en- } \\
\text { cephalitis virus }^{\text {b }}\end{array}$ & Flaviviridae & & Flavivirus & $\begin{array}{l}\text { Infects the olfactory bulb and spreads centrip- } \\
\text { etally after footpad injection. }\end{array}$ & McMinn et al., 1996 \\
\hline $\begin{array}{l}\text { St. Louis encephalitis } \\
\text { virus }^{\text {b }}\end{array}$ & Flaviviridae & & Flavivirus & $\begin{array}{l}\text { Infects ORNs and spreads to the CNS in ham- } \\
\text { sters/mice after intraperitoneal injection. }\end{array}$ & Monath et al., 1983 \\
\hline West Nile virus $^{\mathrm{b}}$ & Flaviviridae & & Flavivirus & $\begin{array}{l}\text { Invades the brain via the olfactory route after } \\
\text { viral aerosol exposure in mice. }\end{array}$ & Nir et al., 1965 \\
\hline Chikungunya virus $^{\mathrm{b}}$ & Togaviridae & & Alphavirus & $\begin{array}{l}\text { Invades the brain via the olfactory route in } \\
\text { mice }^{\text {a }} \text {. }\end{array}$ & $\begin{array}{l}\text { Powers and Logue, } \\
2007\end{array}$ \\
\hline $\begin{array}{l}\text { Venezuelan equine } \\
\text { encephalitis virus }{ }^{\text {b }}\end{array}$ & Togaviridae & & Alphavirus & $\begin{array}{l}\text { Infects ORNs and spreads centripetally in mice } \\
\text { after subcutaneous challenge. }\end{array}$ & Charles et al., 1995 \\
\hline
\end{tabular}

${ }^{a}$ After experimental intranasal infection. ${ }^{b}$ Vector-borne virus in nature but can directly invade the human brain under unusual circumstances (see details in text).

alpha subfamily is estimated to have diverged from the beta and gamma subfamilies approximately 200-220 million years ago and the ancestors of HSV appeared 70-80 million years ago (Mori and Nishiyama, 2005). Thus, the virus-host relationship is fundamentally stable and the virus does not usually precipitate lethal diseases in humans. HSV-1 is transmitted through saliva and respiratory secretions among humans. Typically, HSV-1 asymptomatically infects the respiratory and oropharyngeal mucosa in children. Approximately $90 \%$ of adults are seropositive for HSV-1 and carry the viral genome in a latent form in peripheral ganglions. Reactivation, which may result in herpetic lesions in the skin and mucous membranes, takes place upon exposure to stressors or following immunosuppression. 


\section{Herpes simplex encephalitis (HSE)}

HSE is a rare disease that is associated with a high mortality rate and serious neuropsychological and neurobehavioral sequelae. Patients remain afflicted with HSE for life even if they have been treated very early and have made a good recovery (Kennedy and Chaudhuri, 2002). HSE is usually caused by HSV-1; however, HSV-2 can also be responsible for HSE, especially in neonates and immunocompromised hosts.

The view that HSV-1 can invade the CNS through the olfactory route originally stems from the site-specificity of HSE; the propensity of the virus to localize to the frontotemporal region of the brain and the limbic system (Johnson and Mims, 1968; Twomey et al., 1979). The virus may also spread from the trigeminal ganglion to the temporal and frontal cortices by traveling along the tentorial branches of the trigeminal ganglion to the meninges that cover the frontal and temporal lobes (Davis and Johnson, 1979). However, there has been no direct evidence to support this assumption. Furthermore, because neurons in the trigeminal ganglion principally project to sensory nuclei in the brainstem, the trigeminal pathway can only account for infrequent atypical cases of HSE with brainstem involvement (Livorsi et al., 2010).

A number of lines of evidence favor the olfactory route of neuroinvasion by HSV-1 in HSE patients. Postmortem immunohistochemical mapping analyses of 29 HSE subjects demonstrated the presence of HSV-1 antigens in the olfactory and limbic structures, but not in regions that would indicate invasion via the trigeminal pathway (Esiri, 1982). Furthermore, HSV-related histopathological alterations were detected in the olfactory neuroepithelium, olfactory nerve, and olfactory bulb, but not in the trigeminal ganglion (Twomey et al., 1979; Dinn, 1980; Ojeda et al., 1983). Additionally, life-long olfactory dysfunction has been described in patients who survived HSE, thus highlighting viral damage to the olfactory neural network in the human brain (Landis et al., 2010).

Animal experiments using HSV-1 largely recapitulated the olfactory system damage observed in humans. Following intranasal inoculation with HSV-1 +GC strain, rats contracted acute encephalitis involving regions of the olfactory and limbic systems, including the olfactory bulb, olfactory cortex, amygdala, hippocampus, and entorhinal cortex, and they demonstrated spatial memory deficits (Beers et al., 1993, 1995). Moreover, a mouse model of HSE using the HSV-1 strain $17 \mathrm{syn}^{+}$revealed similar neuropathological and neurobehavioral abnormalities (Armien et al., 2010). Following intranasal infection with the HSV-1 strain SC16, mice developed an asymptomatic and transitory CNS infection that was characterized by viral attack of the olfactory bulb, amygdala, and hippocampus, as well as of the olfactory, cingulate, fron- tal, temporal, and entorhinal cortices (Boggian et al., 2000). The HSV-1 strain H129 targets brain structures within the projections of the olfactory pathway including olfactory and entorhinal cortices upon intranasal inoculation (Hudson et al., 1991). It is important to note that in another study, the SC16 virus targeted the murine olfactory neuroepithelium but rarely reached the olfactory bulb, which was likely due to differences in the animal strains and ages of the mice between the studies (Shivkumar et al., 2013).

\section{Role of HSV accessory genes in the olfactory neuroinvasion}

HSV accessory genes are defined as non-essential genes that are not required for replication in cultured cells but play key roles in virus-host interactions. These genes may help neurovirulent viruses invade the brain through the olfactory route (Mori, 2012). Wild type HSV-2 strain 186 infects a fraction of ORNs without inducing neuronal death and it is transmitted to the CNS where it initiates lethal encephalitis. In sharp contrast, the US3-disrupted mutant strain, L1BR1, immediately triggers neuronal apoptosis in peripheral neurons upon infection, thus blocking viral transmission to the brain (Mori et al., 2006). The US3-repaired mutant strain, L1B-11, behaves similarly to the wild-type virus. These observations suggest that viral US3 protein kinase inhibits virus-induced apoptosis of ORNs, thus enabling efficient viral transmission into the CNS. HSV-1 US3 also plays a role in resistance to IFN. The growth of US3-disrupted virus is significantly suppressed in IFN-treated HEp-2 cells when compared to wild-type and US3-reconstituted virus (Piroozmand et al., 2004). A prominent increase in intracellular expression of TLR3 and IFN-inducible myxovirus resistance A protein have been recorded in US3-deficient HSV-1-infected U937 human monocytic cells, but not in cells infected with corresponding parental and US3-rescued viruses (Peri et al., 2008). Furthermore, HSV-1 US3 protein kinase cooperates with glycoprotein $B$ to rapidly inhibit CD1d antigen presentation and natural killer T-cell activation during the initial antiviral response (Rao et al., 2011). Additionally, ICP0 impairs the activation of IFN regulatory mediators such as IFN- $\gamma$-inducible protein 16 (Lanfranca et al., 2014). Virion host shutoff protein counteracts the antiviral action of IFN-inducible viperin protein (Shen et al., 2014). ICP34.5 confers neurovirulence upon HSV by regulating IFN- $\alpha / \beta$ responses in mice (Davis et al., 2014). Thus, HSV has developed a variety of mechanisms to limit hosts' antiviral responses.

The HSV-1 strain HF10 lacks a functional UL56 and exhibits impaired neuroinvasiveness via the olfactory route in mice (Mori et al., 2005c). UL56 is a C-terminal-anchored type II membrane protein that is expected to be inserted 
into the viral envelope. Interestingly, UL56 protein physically associates with kinesin motor protein KIF1A, and it is most likely involved in anterograde axonal transport of the viral envelope loaded with viral glycoproteins along axons (Koshizuka et al., 2005).

\section{HSV latency and persistency in the central nervous system}

Viruses may silently invade and establish a latent/persistent infection in the olfactory bulb and a particular set of limbic structures. PCR detected HSV-1 DNA in 15.5\% of the olfactory bulbs collected from 97 individuals during forensic postmortem analyses (Liedke et al., 1993). PCR detection of HSV-1 genome in $17.5 \%$ of the olfactory bulbs and less frequently in the amygdala and hippocampus collected from 40 patients dying of non-neurological causes provided evidence in support of olfactory neuroinvasion during the course of a neurologically silent infection (Baringer and Pisani, 1994). Asymptomatic HSV-1 persistence in the olfactory epithelium and bulb was recapitulated using murine models (Drummond et al., 1994; Boggian et al., 2000). It should be noted that HSV infection of the CNS through the olfactory pathway, even if it takes place silently, may bring about learning and behavioral deficiencies in children and adults (Becker, 1995). These findings lead to an assumption that HSV reactivation may originate in the olfactory as well as in limbic structures. Of interest, the olfactory neuronspecific transcription factor, Olf-1, activates the promoter of $R L 2$ and drives the expression of ICP0, which may in turn facilitate productive infection and reactivation within the olfactory system (Devireddy and Jones, 2000). Thus, it is conceivable that HSE in children occurs during the course of primary HSV-1 infection, whereas in adults HSE arises from the reactivation of the virus in the olfactory and/or limbic structures.

On one hand, the recent improvements in sanitizing environments have increased the age of primary HSV-1 infections, and it may bring about new health problems in the near future. On the other hand, HSV-1 frequently establishes continuous and productive infections in the frontal and temporal cortices of aged individuals through expression of HSV-1 accessory genes. This has been implicated, at least in part, in the pathogenesis of Alzheimer's disease (Mori, 2010; Itzhaki, 2014).

\section{Influenza A virus}

Influenza A virus primarily infects the respiratory system in humans and sporadically induces extra-respiratory system complications including influenza encephalitis/ encephalopathy. Influenza A virus neuroinvasion along the olfactory pathway has been extensively investigated using animal models, including mice and ferrets. The recombinant influenza A virus strain, 90/Ho1, which has the RNA segment 2 derived from A/Hong Kong/1/68 (H3N2) and other segments from A/fowl plague/Rostock/34 (H7N1), entered the brain of neonatal mice through the olfactory route following intranasal challenge (Reinacher et al., 1983). This can take place even in the presence of neutralizing antibodies in their serum, thus ruling out the hematogenous spread of the virus. The A/WSN/1933 (H1N1) virus, which is closely related to the $1918 / 1919$ influenza pandemic, invades the olfactory bulb and several interconnected brain structures in mice (Aronsson et al., 2003). The virus can cause transient infection in the CNS, but leads to persistent changes in emotional and cognitive functions as well as elevated transcriptional activity of genes encoding synaptic regulatory proteins in the amygdala and hypothalamus (Kristensson, 2006). By contrast, infection by the non-neurotropic PR8 strain (H1N1) of influenza A virus was restricted to microglia/macrophages in the olfactory nerve fascicle and bulb, but induced widespread CNS production of proinflammatory cytokines including interleukin $1 \beta$ and tumor necrosis factor- $\alpha$ (Leyva-Grado et al., 2009) and influenced the acute phase response including hypothermia (Leyva-Gardo et al., 2010; Zielinski et al., 2013).

We have previously shown that the recombinant influenza A virus strain $\mathrm{R} 404 \mathrm{BP}$, which possesses the neuraminidase and matrix genes from the WSN strain and the rest from the non-neurovirulent A/Aichi/2/68 strain (H3N2), induced apoptosis in ORNs upon infection following intranasal challenge in mice (Mori et al., 2002). Virus-infected ORNs and sustentacular cells in the vicinity upregulated the expression of Fas ligand and activated the c-Jun N-terminal kinase signal transduction pathway. Apoptotic bodies were totally cleared by activated Ibal-immunopositive microglia/macrophages in the olfactory neuroepithelium. Viral components including nucleic acids and proteins remained undetectable in the olfactory bulb. All of the mice survived the infection and failed to exhibit any clinical symptoms. An introduction of one plaque-forming unit of virus directly into the olfactory bulb was sufficient to kill $100 \%$ of the mice. Taken together these findings suggested that virus-induced neuronal apoptosis in ORNs is a protective host response that hinders virus transmission into the brain (Mori et al., 2004). This phenomena, however, appears to be atypical, since many reports documented viral infections of ORNs in the absence of neuronal death in the neuroepithelium.

\section{Highly pathogenic avian influenza}

Recent studies have largely focused on highly pathogenic avian influenza (HPAI) H5N1 viruses that bring about a high 
incidence of neurological complications in many animal species and sporadically in humans (Korteweg and Gu, 2008). During the 1997 Hong Kong incident, the avian H5N1 strains, HK156 and HK483, were isolated from the throat aspirates of a three-year-old boy who was the index case and subsequently developed Reye's syndrome and a 13-year-old girl who was the third case, respectively. Thus far, $\mathrm{H} 5 \mathrm{~N} 1$ virus has been detected in the CNS of a limited number of human cases.

In mouse models, HK483 virus takes the olfactory route for neuroinvasion, although other pathways through the trigeminal, vagal, and sympathetic systems are also possible (Park et al., 2002; Tanaka et al., 2003; Iwasaki et al., 2004). Viremia may not largely contribute to the viral dissemination to the brain. In addition, HPAI A/Vietnam/1203/04 (H5N1) virus invades the murine brain, at least in part, through the olfactory route after snout infection, inducing neuroinflammation and neurodegeneration (Jang et al. 2009). In this experimental system, the virus attacked various brain regions. Of note, phosphorylated alpha-synuclein (pSer129SYN) is detectable in neurons present in infected areas and aggregated alpha-synuclein, a hallmark of neurodegenerative disorders such as Parkinson's and Alzheimer's diseases, in the hippocampus, cortex, and brainstem. In addition, a significant number of dopaminergic neurons in the substantia pars compacta gradually die through a mechanism involving apoptosis, reminiscent of the postencephalitic Parkinsonism that could be associated with the 1918/1919 influenza pandemic (Gamboa, 1974; Kristensson, 2006).

Many H5N1 strains isolated from various Asian countries infected the olfactory neuroepithelium and bulb at early stages in ferrets (Bodewes et al., 2011; Plourde et al., 2012; Schrauwen et al., 2012; Yamada et al., 2012; van Riel et al., 2015). In ferret nose tissues, abundant attachment of the $\mathrm{H} 5 \mathrm{~N} 1$ virus to the apical side of the olfactory neuroepithelium was noted, whereas no attachment of the virus to the apical side of the respiratory epithelium was detected (Schrauwen et al., 2012). The multibasic cleavage site in the hamagglutinin of the $\mathrm{H} 5 \mathrm{~N} 1$ virus plays a critical role in the olfactory spread of the virus (Schrauwen et al., 2012). The virus first appears in mitral cells in the olfactory bulb and spreads centripetally to interconnected structures of the brain. Three-dimensional analysis of viral distribution in the ferret brain unequivocally identified the olfactory system as a major route of viral neuroinvasion (Shinya et al., 2011). The H5N1 virus presented more extensive CNS spread than pandemic $\mathrm{H} 1 \mathrm{~N} 1$ virus, whereas seasonal $\mathrm{H} 3 \mathrm{~N} 2$ virus exhibited minimum neurotropism in ferrets (van den Brand et al., 2012). A novel HPAI virus (H7N9) invades the olfactory bulb following intranasal infection in ferrets (Xu et al. 2013, 2014). It has been demonstrated that the H7N9 virus harbors the nucleoprotein that subverts the antiviral action of human myxovirus resistance A protein (Riegger et al., 2015).

\section{Influenza A virus in human olfactory nervous tissues}

The first evidence of influenza virus entry through the olfactory route in a human was recently described, with viral antigens being detected in the olfactory bulb and tract of postmortem brain samples (van Riel et al., 2014). The patient was an 11-month-old girl with a severe immunodeficiency, the detail of which remains unknown. Sequence analysis of RNA extracted from the bronchoalveolar lavage revealed the presence of a seasonal influenza A H3N2 virus. In addition, three strains of influenza $A$ virus, i.e., seasonal $\mathrm{H} 3 \mathrm{~N} 2$, pandemic $\mathrm{H} 1 \mathrm{~N} 1$, and $\mathrm{H} 5 \mathrm{~N} 1$, have been demonstrated to attach to the apical side of human and ferret olfactory mucosa, strengthening the likelihood of the olfactory route of neuroinvasion in humans (van Riel et al., 2014). Of special significance is the fact that two mutations (L226Q and S228G) in the hemagglutinin gene of A/Hong Kong/1/68 (H3N2) dramatically augmented the viral neurovirulence for the olfactory mucosa (Van Poucke et al., 2013). Thus, CNS invasion of seasonal H3N2 virus could be explained not only by immune defects of the host but also by the increased neurotropism of the virus, precipitated by a few mutations in the viral genome.

Furthermore, indirect evidence supports influenza A virus entry into the human brain via the olfactory route. H3N2 virus RNA could frequently be detected in the CSF of children with influenza-associated acute encephalitis/ encephalopathy at early stages of infection (Fujimoto et al., 1998). A previously healthy 26-year-old man developed a fatal encephalopathy without any respiratory disease. Real-time PCR detected influenza A (H1N1) pdm09 virus in a brain biopsy specimen but did not reveal the presence of the viral RNA in the lung (Simon et al., 2013). In addition, H5N1 virus was detected in the CSF of the four-year-old boy who died of acute encephalitis, without any respiratory disease at the moment of hospitalization (de Jong et al., 2005).

\section{Concluding remarks}

Experimentally, a wide variety of neurotropic viruses make use of the olfactory route for neuroinvasion into the CNS. In humans, however, there is a scantiness of direct evidence demonstrating this route of CNS entry because of the restricted availability of human nervous tissues from the nasal epithelium to the olfactory bulb/tract. Detailed investigation of such human specimens will expand our understanding of the neuropathogenesis of virus-induced encephalitis/encephalopathy and some neurodegenerative disorders in which early olfactory dysfunction and olfactory bulb pathology have much been described, such as Alzheimer's and Parkinson's diseases (Doorn et al., 2014). Furthermore, early and prominent olfactory dysfunction and 
pathology are common in demyelinating disorders including multiple sclerosis (DeLuca et al., 2015). Common respiratory viruses may be involved in the pathogenesis of these diseases (Majde, 2010). According to the hit-and-run theory, although viruses are eventually eradicated by the immune system at early stages of the infection, they have a potential to trigger CNS disorders by inducing severe neuroinflammation from the olfactory network (Leyva-Grado et al., 2009).

Finally, intranasal delivery of drugs, nucleic acids, and cells through the olfactory conduit to the CNS will drastically improve therapeutic and prophylactic approaches to neurological and neuropsychiatric diseases in the future (Dhuria et al., 2010; Kanazawa T et al., 2013; Danielyan et al., 2014).

\section{References}

Baringer JR, Pisani P (1994): Herpes simplex virus genomes in human nervous system tissue analyzed by polymerase chain reaction. Ann. Neurol. 36, 823-829. http://dx.doi. org/10.1002/ana.410360605

Armien AG, Hu S, Little MR, Robinson N, Lokensgard JR, Low WC, Cheeran MC (2010): Chronic cortical and subcortical pathology with associated neurological deficits ensuing experimental herpes encephalitis. Brain Pathol. 20, 738-750. http://dx.doi.org/10.1111/j.1750-3639.2009.00354.x

Aronsson F, Robertson B, Ljunggren HG, Kristensson $\mathrm{K}$ (2003): Invasion and persistance of the neuroadapted influenza virus A/WSN/33 in the mouse olfactory system. Viral Immunol. 16, 415-423. http://dx.doi. org/10.1089/088282403322396208

Becker Y (1995): HSV-1 brain infection by the olfactory nerve route and virus latency and reactivation may cause learning and behavioral deficiencies and violence in children and adults: A point of view. Virus Genes 10, 217-226. http:// dx.doi.org/10.1007/BF01701811

Beers DR, Henkel JS, Schaefer DC, Rose JW, Stroop WG (1993): Neuropathology of herpes simplex virus encephalitis in a rat seizure model. J. Neuropathol. Exp. Neurol. 52, 241-252. http://dx.doi.org/10.1097/00005072199305000-00008

Beers DR, Henkel JS, Kesner RP, Stroop WG (1995): Spatial recognition memory deficits without notable CNS pathology in rats following herpes simplex encephalitis. J. Neurol. Sci. 131, 119-127. http://dx.doi.org/10.1016/0022-510X(95)00099-N

Bennett RS, Cress CM, Ward JM, Firestone CY, Murphy BR, Whitehead SS (2008): La Crosse virus infectivity, pathogenesis, and immunogenicity in mice and monkeys. Virol. J. 5, 25. http://dx.doi.org/10.1186/1743-422X-5-25

Berri F, Haffar G, Lê VB, Sadewasser A, Paki K, Lina B, Wolff T, Riteau B (2014): Annexin V incorporated into influenza virus particles inhibits gamma interferon signaling and promotes viral replication. J. Virol. 88, 11215-11228. http://dx.doi.org/10.1128/JVI.01405-14
Bodewes R, Kreijtz JH, van Amerongen G, Fouchier RA, Osterhaus AD, Rimmelzwaan GF, Kuiken T (2011): Pathogenesis of influenza $\mathrm{A} / \mathrm{H} 5 \mathrm{~N} 1$ virus infection in ferrets differs between intranasal and intratracheal routes of inoculation. Am. J. Pathol. 179, 30-36. http://dx.doi.org/10.1016/j. ajpath.2011.03.026

Boggian I, Buzzacaro E, Calistri A, Calvi P, Cavaggioni A, Mucignat-Caretta C, Palu G (2000): Asymptomatic herpes simplex type 1 virus infection of the mouse brain. J. Neurovirol. 6, 303-313. http://dx.doi. org/10.3109/13550280009030756

Boivin N, Sergerie Y, Rivest S, Boivin G (2008): Effect of pretreatment with Toll-like receptor agonists in a mouse model of herpes simplex virus type 1 encephalitis. J. Infect. Dis. 198, 664-672. http://dx.doi.org/10.1086/590671

Carbone KM, Duchala CS, Griffin JW, Kincaid AL, Narayan O (1987): Pathogenesis of Borna disease in rats: Evidence that intra-axonal spread is the major route for virus dissemination and the determinant for disease incubation. J. Virol. 61, 3431-3440.

Carty M, Reinert L, Paludan SR, Bowie AG (2014): Innate antiviral signalling in the central nervous system. Trends Immunol. 35, 79-87. http://dx.doi.org/10.1016/j.it.2013.10.012

Charles PC, Walters E, Margolis F, Johnston RE (1995): Mechanism of neuroinvasion of Venezuelan equine encephalitis virus in the mouse. Virology 208, 662-671. http://dx.doi. org/10.1006/viro.1995.1197

Conomy JP, Leibovitz A, McCombs W, Stinson J (1977): Airborne rabies encephalitis: Demonstration of rabies virus in the human central nervous system. Neurology 27, 67-69. http://dx.doi.org/10.1212/WNL.27.1.67

Crotty S, Hix L, Sigal LJ, Andino R (2002): Poliovirus pathogenesis in a new poliovirus receptor transgenic mouse model: age-dependent paralysis and a mucosal route of infection. J. Gen. Virol. 83, 1707-1720. http://dx.doi. org/10.1099/0022-1317-83-7-1707

Danielyan L, Beer-Hammer S, Stolzing A, Schäfer R, Siegel G, Fabian C, Kahle P, Biedermann T, Lourhmati A, Buadze M, Novakovic A, Proksch B, Gleiter CH, Frey WH, Schwab M (2014): Intranasal delivery of bone marrow-derived mesenchymal stem cells, macrophages, and microglia to the brain in mouse models of Alzheimer's and Parkinson's disease. Cell Transplant. 23 (Suppl. 1), 123-139. http://dx.doi.org/10.3727/096368914X684970

Davis KL, Korom M, Morrison LA (2014): Herpes simplex virus 2 ICP34.5 confers neurovirulence by regulating the type I interferon response. Virology 468-470, 330-339. http:// dx.doi.org/10.1016/j.virol.2014.08.015

Davis LE and Johnson RT (1979): An explanation for the localization of herpes simplex encephalitis? Ann. Neurol. 5, 2-5. http://dx.doi.org/10.1002/ana.410050103

de Jong MD, Bach VC, Phan TQ, Vo MH, Tran TT, Nguyen BH, Beld M, Le TP, Truong HK, Nguyen VV, Tran TH, Do QH, Farrar J (2005):. Fatal avian influenza A (H5N1): in a child presenting with diarrhea followed by coma. N. Engl. J. Med. 352, 686-691. http://dx.doi.org/10.1056/ nejmoa044307 
DeLuca GC, Joseph A, George J, Yates RL, Hamard M, Hofer M, Esiri MM (2015): Olfactory pathology in central nervous system demyelinating diseases. Brain Pathol. 25, 543-551. http://dx.doi.org/10.1111/bpa.12209

Devireddy LR, Jones CJ (2000): Olf-1, a neuron-specific transcription factor, can activate the herpes simplex virus type 1 -infected cell protein 0 promoter. J. Biol. Chem. 275, 77-81. http://dx.doi.org/10.1074/jbc.275.1.77

Dhuria SV, Hanson LR, Frey WH 2nd (2010): Intranasal delivery to the central nervous system: mechanisms and experimental considerations. J. Pharm. Sci. 99, 1654-1673.

Diefenbach RJ, Miranda-Saksena M, Douglas MW, Cunningham AL (2008): Transport and egress of herpes simplex virus in neurons. Rev. Med. Virol. 18, 35-51. http://dx.doi. org $/ 10.1002 /$ rmv.560

Dinn JJ (1980): Transolfactory spread of virus in herpes simplex encephalitis. Br. Med. J. 281, 1392. http://dx.doi. org/10.1136/bmj.281.6252.1392

Doorn KJ, Goudriaan A, Blits-Huizinga C, Bol JG, Rozemuller AJ, Hoogland PV, Lucassen PJ, Drukarch B, van de Berg WD, van Dam AM (2014): Increased amoeboid microglial density in the olfactory bulb of Parkinson's and Alzheimer's patients. Brain Pathol. 24, 152-165. http://dx.doi. org/10.1111/bpa.12088

Drummond CW, Eglin RP, Esiri MM (1994): Herpes simplex virus encephalitis in a mouse model: PCR evidence for CNS latency following acute infection. J. Neurol. Sci. 127, 159163. http://dx.doi.org/10.1016/0022-510X(94)90068-X

Dups J, Middleton D, Yamada M, Monaghan P, Long F, Robinson R, Marsh GA, Wang LF (2012): A new model for Hendra virus encephalitis in the mouse. PLoS One 7, e40308. http://dx.doi.org/10.1371/journal.pone.0040308

Esiri MM (1982): Herpes simplex encephalitis. An immunohistological study of the distribution of viral antigen within the brain. J. Neurol. Sci. 54, 209-226. http://dx.doi. org/10.1016/0022-510X(82)90183-6

Faber HK, Silverberg RJ, Dong L (1944): Poliomyelitis in the cynomolgus monkey: III. Infection by inhalation of droplet nuclei and the nasopharyngeal portal of entry, with a note on this mode of infection in rhesus. J. Exp. Med. 80, 39-57. http://dx.doi.org/10.1084/jem.80.1.39

Fujimoto S, Kobayashi M, Uemura O, Iwasa M, Ando T, Katoh T, Nakamura C, Maki N, Togari H, Wada Y (1998): PCR on cerebrospinal fluid to show influenza-associated acute encephalopathy or encephalitis. Lancet 352, 873-875. http://dx.doi.org/10.1016/S0140-6736(98)12449-2

Gamboa ET, Wolf A, Yahr MD, Harter DH, Duffy PE, Barden H, Hsu KC (1974): Influenza virus antigen in postencephalitic parkinsonism brain. Arch. Neurol. 31, 228-232. http:// dx.doi.org/10.1001/archneur.1974.00490400042003

Gizurarson S (2012): Anatomical and histological factors affecting intranasal drug and vaccine delivery. Curr. Drug Deliv. 9, 566582. http://dx.doi.org/10.2174/156720112803529828

Haga S, Yoshimura M, Motoi Y, Arima K, Aizawa T, Ikuta K, Tashiro M, Ikeda K (1997): Detection of Borna disease virus genome in normal human brain tissue. Brain Res. 770, 307-309. http://dx.doi.org/10.1016/S0006-8993(97)00903-7
Harberts E, Yao K, Wohler JE, Maric D, Ohayon J, Henkin R, Jacobson S (2011): Human herpesvirus- 6 entry into the central nervous system through the olfactory pathway. Proc. Natl. Acad. Sci. USA 108, 13734-13739. http:// dx.doi.org/10.1073/pnas.1105143108

Hudson SJ, Dix RD, Streilein JW (1991): Induction of encephalitis in SJL mice by intranasal infection with herpes simplex virus type 1: A possible model of herpes simplex encephalitis in humans. J. Infect. Dis. 163, 720-727. http://dx.doi. org/10.1093/infdis/163.4.720

Ibarra-Soria X, Levitin MO, Logan DW (2014): The genomic basis of vomeronasal-mediated behaviour. Mamm. Genome 25, 75-86. http://dx.doi.org/10.1007/s00335-013-9463-1

Itzhaki RF (2014): Herpes simplex virus type 1 and Alzheimer's disease: increasing evidence for a major role of the virus. Front. Aging Neurosci. Volume, pages??? Johnson RT, Mims CA (1968): Pathogenesis of viral infections of the nervous system. N. Engl. J. Med. 278, 23-30.

Iwasaki T, Itamura S, Nishimura H, Sato Y, Tashiro M, Hashikawa T, Kurata T (2004): Productive infection in the murine central nervous system with avian influenza virus A (H5N1): after intranasal inoculation. Acta Neuropathol. 108, 485-492. http://dx.doi.org/10.1007/s00401-004-0909-0

Jang H, Boltz D, Sturm-Ramirez K, Shepherd KR, Jiao Y, Webster R, Smeyne RJ (2009): Highly pathogenic H5N1 influenza virus can enter the central nervous system and induce neuroinflammation and neurodegeneration. Proc. Natl. Acad. Sci. USA 106, 14063-14068. http://dx.doi. org/10.1073/pnas.0900096106

Kalinke U, Bechmann I, Detje CN (2011): Host strategies against virus entry via the olfactory system. Virulence 2, 367-370. http://dx.doi.org/10.4161/viru.2.4.16138

Kanazawa T, Akiyama F, Kakizaki S, Takashima Y, Seta Y (2013): Delivery of siRNA to the brain using a combination of nose-to-brain delivery and cell-penetrating peptidemodified nano-micelles. Biomaterials 34, 9220-9226. http://dx.doi.org/10.1016/j.biomaterials.2013.08.036

Kennedy PGE, Chaudhuri A (2002): Herpes simplex encephalitis. J. Neurol. Neurosurg. Psychiatry 73, 237-238. http://dx.doi. org/10.1136/jnnp.73.3.237

Korteweg C, Gu J (2008): Pathology, molecular biology, and pathogenesis of avian influenza A (H5N1): infection in humans. Am. J. Pathol. 172, 1155-1170. http://dx.doi.org/10.2353/ ajpath.2008.070791

Koshizuka T, Kawaguchi Y, Nishiyama Y (2005): Herpes simplex virus type 2 membrane protein UL56 associates with the kinesin motor protein KIF1A. J. Gen. Virol. 86, 527-533. http://dx.doi.org/10.1099/vir.0.80633-0

Kristensson K (2006): Avian influenza and the brain - Comments on the occasion of resurrection of the Spanish flu virus. Brain Res. Bull. 68, 406-413. http://dx.doi.org/10.1016/j. brainresbull.2005.11.022

Kristensson K (2011): Microbes' roadmap to neurons. Nat. Rev. Neurosci. 12, 345-357 http://dx.doi.org/10.1038/ $\underline{\operatorname{nrn} 3029}$

Kuno G (2001): Transmission of arboviruses without involvement of arthropod vectors. Acta Virol. 45, 139-150. 
Lafay F, Coulon P, Astic L, Saucier D, Riche D, Holley A, Flamand A (1991): Spread of the CVS strain of rabies virus and of the avirulent mutant AvO1 along the olfactory pathways of the mouse after intranasal inoculation. Virology 183, 320-330. http://dx.doi.org/10.1016/0042-6822(91) $90145-2$

Landis BN, Vodicka J, Hummel T (2010): Olfactory dysfunction following herpetic meningoencephalitis. J. Neurol. 257, 439-443. http://dx.doi.org/10.1007/s00415-009-5344-7

Lanfranca MP, Mostafa HH, Davido DJ (2014): HSV-1 ICP0: An E3 ubiquitin ligase that counteracts host intrinsic and innate immunity. Cells 3, 438-454. http://dx.doi.org/10.3390/ cells 3020438

Leyva-Grado VH, Churchill L, Wu M, Williams TJ, Taishi P, Majde JA, Krueger JM (2009): Influenza virus- and cytokineimmunoreactive cells in the murine olfactory and central autonomic nervous systems before and after illness onset. J. Neuroimmunol. 211, 73-83. http://dx.doi.org/10.1016/j. jneuroim.2009.03.016

Leyva-Grado VH, Churchill L, Harding J, Krueger JM (2010): The olfactory nerve has a role in the body temperature and brain cytokine responses to influenza virus. Brain Behav. Immun. 24, 281-288. http://dx.doi.org/10.1016/j. bbi.2009.10.007

Liedmann S, Hrincius ER, Guy C, Anhlan D, Dierkes R, Carter R, Wu G, Staeheli P, Green DR, Wolff T, McCullers JA, Ludwig S, Ehrhardt C (2014): Viral suppressors of the RIG-1-mediated interferon response are pre-packed in influenza virions. Nat. Commun. 5, 5645. http://dx.doi. org/10.1038/ncomms6645

Liedtke W, Opalka B, Zimmermann CW, Lignitz E (1993): Age distribution of latent herpes simplex virus 1 and varicella-zoster virus genome in human nervous system. J. Neurol. Sci. 116, 6-11. http://dx.doi.org/10.1016/0022510X(93)90082-A

Livorsi D, Anderson E, Qureshi S, Howard M, Wang YF, FrancoParedes C (2010): Brainstem encephalitis: an unusual presentation of herpes simplex virus infection. J. Neurol. 257, 1432-1437. http://dx.doi.org/10.1007/s00415-010-5600-x

Loseva E, Yuan TF, Karnup S (2009): Neurogliogenesis in the mature olfactory system: A possible protective role against infection and toxic dust. Brain Res. Rev. 59, 374-387. http:// dx.doi.org/10.1016/j.brainresrev.2008.10.004

Majde JA (2010): Neuroinflammation resulting from covert brain invasion by common viruses - a potential role in local and global neurodegeneration. Med. Hypotheses 75, 204-213. http://dx.doi.org/10.1016/j.mehy.2010.02.023

McMinn PC, Dalgarno L, Weir RC (1996): A comparison of the spread of Murray Valley encephalitis viruses of high or low neuroinvasiveness in the tissues of Swiss mice after peripheral inoculation. Virology 220, 414-423. http:// dx.doi.org/10.1006/viro.1996.0329

Monath TP, Cropp CB, Harrison AK (1983): Mode of entry of a neurotropic arbovirus into the central nervous system. Lab. Invest. 48, 399-410.

Morales JA, Herzog S, Kompter C, Frese K, Rott R (1988): Axonal transport of Borna disease virus along olfactory path- ways in spontaneously and experimentally infected rats. Med. Microbiol. Immunol. 177, 51-68. http://dx.doi. org/10.1007/BF00189527

Mori I, Goshima F, Imai Y, Kohsaka S, Sugiyama T, Yoshida T, Yokochi T, Nishiyama Y, Kimura Y (2002): Olfactory receptor neurons prevent dissemination of neurovirulent influenza A virus into the brain by undergoing virusinduced apoptosis. J. Gen. Virol. 83, 2109-2116. http:// dx.doi.org/10.1099/0022-1317-83-9-2109

Mori I, Nishiyama Y, Yokochi T, Kimura Y (2004): Virus-induced neuronal apoptosis as pathological and protective responses of the host. Rev. Med. Virol. 14, 209-216 http:// dx.doi.org/10.1002/rmv.426

Mori I, Nishiyama Y, Yokochi T, Kimura Y (2005a): Olfactory transmission of neurotropic viruses. J. Neurovirol. 11, 129-137. http://dx.doi.org/10.1080/13550280590922793

Mori I, Goshima F, Ito H, Koide N, Yoshida T, Yokochi T, Kimura Y, Nishiyama Y (2005b): The vomeronasal chemosensory system as a route of neuroinvasion by herpes simplex virus. Virology 334, 51-58. http://dx.doi.org/10.1016/j. virol.2005.01.023

Mori I, Liu B, Goshima F, Ito H, Koide N, Yoshida T, Yokochi T, Kimura Y, Nishiyama Y (2005c): HF10, an attenuated herpes simplex virus (HSV): type 1 clone, lacks neuroinvasiveness and protects mice against lethal challenge with HSV types 1 and 2. Microb. Infect. 7, 1492-1500. http:// dx.doi.org/10.1016/j.micinf.2005.05.007

Mori I, Nishiyama Y (2005): Herpes simplex virus and varicellazoster virus: why do these human alphaherpesviruses behave so differently from one another? Rev. Med. Virol. 15, 393-406. http://dx.doi.org/10.1002/rmv.478

Mori I, Goshima F, Watanabe D, Ito H, Koide N, Yoshida T, Liu B, Kimura Y, Yokochi T, Nishiyama Y (2006): Herpes simplex virus US3 protein kinase regulates virus-induced apoptosis in olfactory and vomeronasal chemosensory neurons in vivo. Microb. Infect. 8, 1806-1812. http:// dx.doi.org/10.1016/j.micinf.2006.02.018

Mori I (2010): Herpes simplex virus type 1 persists in the aged brain through hypothetical expression of accessory genes. J. Neurovirol. 16, 203-207. http://dx.doi. org/10.3109/13550281003739040

Mori I (2012): Herpes simplex virus US3 protein kinase regulates host responses and determines neurovirulence. Microbiol. Immunol. 56, 351-355. http://dx.doi.org/10.1111/j.1348$\underline{0421.2012 .00461 . x}$

Munster VJ, Prescott JB, Bushmaker T, Long D, Rosenke R, Thomas T, Scott D, Fischer ER, Feldmann H, de Wit E (2012): Rapid Nipah virus entry into the central nervous system of hamsters via the olfactory route. Sci. Rep. 2, 736. http:// dx.doi.org/10.1038/srep00736

Nir Y, Beemer A, Goldwasser RA (1965): West Nile virus infection in mice following exposure to a viral aerosol. Br. J. Exp. Pathol. 46, 443-449.

Oboti L, Peretto P, De Marchis S, Fasolo A (2011): From chemical neuroanatomy to an understanding of the olfactory system. Eur. J. Histochem. 55, e35. http://dx.doi.org/10.4081/ ejh.2011.e35 
Ojeda VJ, Archer M, Robertson TA, Bucens MR (1983): Necropsy study of the olfactory portal of entry in herpes simplex encephalitis. Med. J. Aust. 1, 79-81.

Park CH, Ishinaka M, Takada A, Kida H, Kimura T, Ochiai K, Umemura $\mathrm{T}$ (2002): The invasion routes of neurovirulent A/Hong Kong/483/97 (H5N1): influenza virus into the central nervous system after respiratory infection in mice. Arch. Virol. 147, 1425-1436. http://dx.doi.org/10.1007/ s00705-001-0750-X

Peri P, Mattila RK, Kantola H, Broberg E, Karttunen HS, Waris M, Vuorinen T, Hukkanen V (2008): Herpes simplex virus type 1 Us3 gene deletion influences toll-like receptor responses in cultured monocytic cells. Virol. J. 5, 140. http://dx.doi.org/10.1186/1743-422X-5-140

Piroozmand A, Koyama AH, Shimada Y, Fujita M, Arakawa T, Adachi A (2004): Role of Us3 gene of herpes simplex virus type 1 for resistance to interferon. Int. J. Mol. Med. 14, 641-645. http://dx.doi.org/10.3892/ijmm.14.4.641

Plourde JR, Pyles JA, Layton RC, Vaughan SE, Tipper JL, Harrod KS (2012): Neurovirulence of H5N1 infection in ferrets is mediated by multifocal replication in distinct permissive neuronal cell regions. PLoS One 7, e46605. http://dx.doi. org/10.1371/journal.pone.0046605

Powers AM, Logue CH (2007): Changing patterns of chikungunya virus: re-emergence of a zoonotic arbovirus. J. Gen. Virol. 88, 2363-2377. http://dx.doi.org/10.1099/vir.0.82858-0

Rao P, Pham HT, Kulkarni A, Yang Y, Liu X, Knipe DM, Cresswell P, Yuan W (2011): Herpes simplex virus 1 glycoprotein B and US3 collaborate to inhibit CD1d antigen presentation and NKT cell function. J. Virol. 85, 8093-8104. http:// dx.doi.org/10.1128/JVI.02689-10

Reinacher M, Bonin J, Narayan O, Scholtissek C (1983): Pathogenesis of neurovirulent influenza A virus infection in mice. Route of entry of virus into brain determines infection of different populations of cells. Lab. Invest. 49, 686-692.

Riegger D, Hai R, Dornfeld D, Mänz B, Leyva-Grado V, SánchezAparicio MT, Albrecht RA, Palese P, Haller O, Schwemmle M, Garcia-Sastre A, Kochs G, Schmolke M (2015): The nucleoprotein of newly emerged H7N9 influenza A virus harbors a unique motif conferring resistance to antiviral human MxA. J. Virol. 89, 2241-2252. http://dx.doi. org/10.1128/JVI.02406-14

Rodriguez S, Sickles HM, DeLeonardis C, Alcaraz A, Gridley T, Lin DM (2008): Notch2 is required for maintaining sustentacular cell function in the adult mouse main olfactory epithelium. Dev. Biol. 314, 40-58. http://dx.doi. org/10.1016/j.ydbio.2007.10.056

Sabin AB, Olitsky PK (1938): Fate of nasally instilled poliomyelitis virus in normal and convalescent monkeys with special reference to the problem of host to host transmission. J. Exp. Med. 68, 39-62. http://dx.doi.org/10.1084/ jem.68.1.39

Sauder C, Staeheli P (2003): Rat model of Borna disease virus transmission: Epidemiological implications. J. Virol. 77, 12886-12890. http://dx.doi.org/10.1128/JVI.77.23.12886$\underline{12890.2003}$

Schrauwen EJ, Herfst S, Leijten LM, van Run P, Bestebroer TM, Linster M, Bodewes R, Kreijtz JH, Rimmelzwaan GF,
Osterhaus AD, Fouchier RA, Kuiken T, van Riel D (2012): The multibasic cleavage site in $\mathrm{H} 5 \mathrm{~N} 1$ virus is critical for systemic spread along the olfactory and hematogenous routes in ferrets. J. Virol. 86, 3975-3984. http://dx.doi. org/10.1128/JVI.06828-11

Shen G, Wang K, Wang S, Cai M, Li ML, Zheng C (2014): Herpes simplex virus 1 counteracts viperin via its virion host shutoff protein UL41. J. Virol. 88, 12163-12166. http:// dx.doi.org/10.1128/JVI.01380-14

Shinya K, Makino A, Hatta M, Watanabe S, Kim JH, Hatta Y, Gao P, Ozawa M, Le QM, Kawaoka Y (2011): Subclinical brain injury caused by $\mathrm{H} 5 \mathrm{~N} 1$ influenza virus infection. J. Virol. 85, 5202-5207. http://dx.doi.org/10.1128/JVI.00239-11

Shivkumar M, Milho R, May JS, Nicoll MP, Efstathiou S, Stevenson PG (2013): Herpes simplex virus 1 targets the murine olfactory neuroepithelium for host entry. J. Virol. 87, 10477-10488. http://dx.doi.org/10.1128/JVI.01748-13

Simon M, Hernu R, Cour M, Casalegno JS, Lina B, Argaud L (2013): Fatal influenza A (H1N1): pdm09 encephalopathy in immunocompetent man. Emerg. Infect. Dis. 19, 1005-1007. http://dx.doi.org/10.3201/eid1906.130062

Smithson LJ, Kawaja MD (2010): Microglial/macrophage cells in mammalian olfactory nerve fascicles. J. Neurosci. Res. $88,858-865$.

Suh HS, Brosnan CF, Lee SC (2009): Toll-like receptors in CNS viral infections. Curr. Top. Microbiol. Immunol. 336, 63-81. http://dx.doi.org/10.1007/978-3-642-00549-7 4

Suzuki Y, Schafer J, Farbman AI (1995): Phagocytic cells in the rat olfactory epithelium after bulbectomy. Exp. Neurol. 136, 225-233. http://dx.doi.org/10.1006/exnr.1995.1099

Tan CS, Stevenson PG (2014): B cell response to herpesvirus infection of the olfactory neuroepithelium. J. Virol. 88 , 14030-14039. http://dx.doi.org/10.1128/JVI.02345-14

Tanaka H, Park CH, Ninomiya A, Ozaki H, Takada A, Umemura T, Kida H (2003): Neurotropism of the 1997 Hong Kong H5N1 influenza virus in mice. Vet. Microbiol. 95, 1-13. http://dx.doi.org/10.1016/S0378-1135(03)00132-9

Twomey JA, Barker CM, Robinson G, Howell DA (1979): Olfactory mucosa in herpes simplex encephalitis. J. Neurol. Neurosurg. Psychiatry 42, 983-987. http://dx.doi.org/10.1136/ innp.42.11.983

van den Brand JM, Stittelaar KJ, van Amerongen G, Reperant L, de Waal L, Osterhaus AD, Kuiken T (2012): Comparison of temporal and spatial dynamics of seasonal H3N2, pandemic $\mathrm{H} 1 \mathrm{~N} 1$ and highly pathogenic avian influenza H5N1 virus infections in ferrets. PLoS One 7, e42343. http://dx.doi.org/10.1371/journal.pone.0042343

van den Pol AN, Ding S, Robek MD (2014): Long-distance interferon signaling within the brain blocks virus spread. J. Virol. 88, 3695-3704. http://dx.doi.org/10.1128/JVI.03509-13

Van Poucke S, Uhlendorff J, Wang Z, Billiau V, Nicholls J, Matrosovich M, Van Reeth K (2013): Effect of receptor specificity of A/Hong Kong/1/68 (H3N2): influenza virus variants on replication and transmission in pigs. Influenza Other Respir. Viruses 7, 151-159. http://dx.doi.org/10.1111/ j.1750-2659.2012.00376.x

van Riel D, Leijten LM, Verdijk RM, GeurtsvanKessel C, van der Vries E, van Rossum AM, Osterhaus AD, Kuiken T 
(2014): Evidence for influenza virus CNS invasion along the olfactory route in an immunocompromised infant. J. Infect. Dis. 210, 419-423. http://dx.doi.org/10.1093/ infdis/jiu097

van Riel D, Verdijk R, Kuiken T (2015): The olfactory nerve: a shortcut for influenza and other viral diseases into the central nervous system. J. Pathol. 235, 277-287. http:// dx.doi.org/10.1002/path.4461

Verhaeghe J, Gheysen R, Enzlin P (2013): Pheromones and their effect on women's mood and sexuality. Facts Views Vis. Obgyn. 5, 189-195.

Vilensky JA (2014): The neglected cranial nerve: Nervus terminalis (cranial nerve N): Clin. Anat. 27, 46-53. http://dx.doi. org/10.1002/ca.22130

Xu L, Bao L, Deng W, Zhu H, Chen T, Lv Q, Li F, Yuan J, Xiang Z, Gao K, Xu Y, Huang L, Li Y, Liu J, Yao Y, Yu P, Yong W, Wei Q, Zhang L, Qin C (2013): The mouse and ferret models for studying the novel avian-origin human influenza A (H7N9): virus. Virol J. 10, 253. http://dx.doi. org/10.1186/1743-422X-10-253

Xu L, Bao L, Deng W, Dong L, Zhu H, Chen T, Lv Q, Li F, Yuan J, Xiang Z, Gao K, Xu Y, Huang L, Li Y, Liu J, Yao Y, Yu P, Li X, Huang W, Zhao X, Lan Y, Guo J, Yong W, Wei Q, Chen H, Zhang L, Qin C (2014): Novel avian-origin human influenza A (H7N9): can be transmitted between ferrets via respiratory droplets. J. Infect. Dis. 209, 551-556. http:// dx.doi.org/10.1093/infdis/jit474

Yamada M, Nakamura K, Yoshii M, Kaku Y, Narita M (2009): Brain lesions induced by experimental intranasal infection of Japanese encephalitis virus in piglets. J. Comp. Pathol. 141, 156-162. http://dx.doi.org/10.1016/j. jcpa.2009.04.006

Yamada M, Bingham J, Payne J, Rookes J, Lowther S, Haining J, Robinson R, Johnson D, Middleton D (2012): Multiple routes of invasion of wild-type Clade 1 highly pathogenic avian influenza $\mathrm{H} 5 \mathrm{~N} 1$ virus into the central nervous system (CNS): after intranasal exposure in ferrets. Acta Neuropathol. 124, 505-516. http://dx.doi.org/10.1007/ s00401-012-1010-8

Zielinski MR, Souza G, Taishi P, Bohnet SG, Krueger JM (2013): Olfactory bulb and hypothalamic acute-phase responses to influenza virus: effects of immunization. Neuroimmunomodulation 20, 323-333. http://dx.doi. org $/ 10.1159 / 000351716$

Zlotnik I, Grant DP (1976): Further observations on subacute sclerosing encephalitis in adult hamsters: The effects of intranasal infections with Langat virus, measles virus and SSPE-measles virus. Br. J. Exp. Path. 57,49. 